\title{
高津川河口の砂州変形と航路埋塞の数值シミュレーション

\author{
Numerical Simulations of Channel Infilling and Sand Bar Deformation around Mouth of \\ Takatsu River
}

\author{
小野信幸 ${ }^{1} \cdot$ 黒木敬司 $^{2} \cdot$ 石本健治 $^{3} \cdot$ 伊東啓勝 $^{4}$ \\ Nobuyuki ONO, Keiji KUROKI, Kenji ISHIMOTO and Yoshimasa ITO
}

\begin{abstract}
Masuda port is located in both sides of the mouth of Takatsu River, the access channel of which passes behind a rivermouth bar. This study intends to develop a tool for examination of countermeasures against channel infilling which is very linked with deformation of river-mouth bar. First, the relation between the sand bar deformation and channel infilling has been examined for the river mouth area of Takatsu River through analysis of aerial photos, current and wave data, bathymetric survey data, and so on. As the results, two dominant processes of flushing sand bar due to flood and reformation of sand bar by waves are confirmed. Also, numerical simulations for the two dominant processes have been conducted and the reproducibility of the model has been examined.
\end{abstract}

\section{1.はじめに}

高津川は島根県西部に抒いて日本海へ注ぐ流域面積 1090km²の一級河川である. 高津川河口部の左右岸には, 図-1中に示すように, 益田港（高津地区, 大塚地区）が 立地し, 河口砂州の背後に高津航路, 導流堤間を通る大 塚航路が位置している。益田港では, 1999年度に海岸整 備計画の見直しと港湾整備計画が検討され, 現在, 防波 堤等の整備が進められているところである.

このような中, 2010 年 7 月の大雨による出水で, 河口 内の航路を守る形で残っていた砂州が決壊して沖側に流 出し, その後, 2011 年 1 月の冬期風浪によって, 沖側に 堆積していた土砂が河口内航路へ押し込まれ, 高津航路 を埋塞し船船航行ができない状況となった。

本研究は, 河口航路の埋塞対策を検討するッールを 構築することを目的とする. 高津川河口を対象に, 出 水による砂州の決壊・流出, 波浪による土砂の押し込 みなどの土砂移動の穾態を把握した上で, 河口域の地 形変化と航路埋塞状況に関する数值シミュレーション を行った。

\section{2. 河口地形変化の実態把握}

高津川河口の地形変化の実態を把握するため, 空中写 真, 河道及び沿岸部の測量デー夕, 底質デー夕, 航路の 維持浚渫量, 波浪及び流量デー夕の収集・整理を行った.

\section{(1) 砂州形状の変遷}

図-2は，1990年から2011年までの空中写真を収集し，

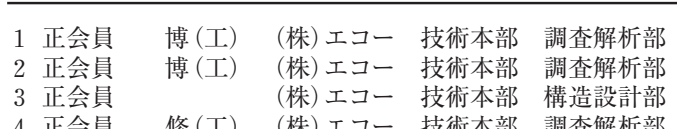

4 正会員一修(丁) - (株) エコー 技術木部 調查解折部

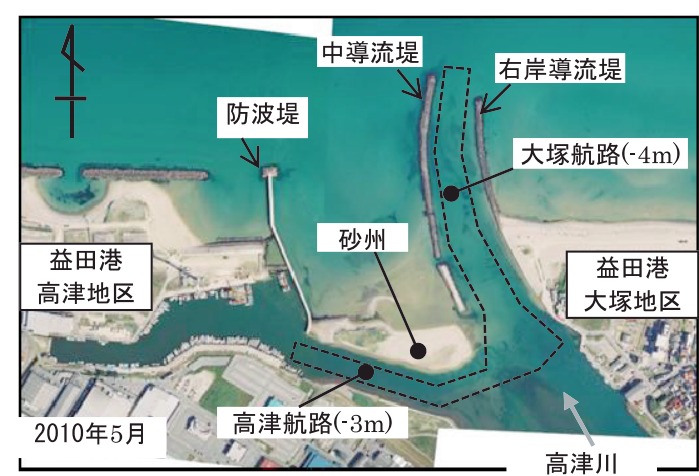

図-1 高津川河口砂州の形状（2010年5月）と航路位置

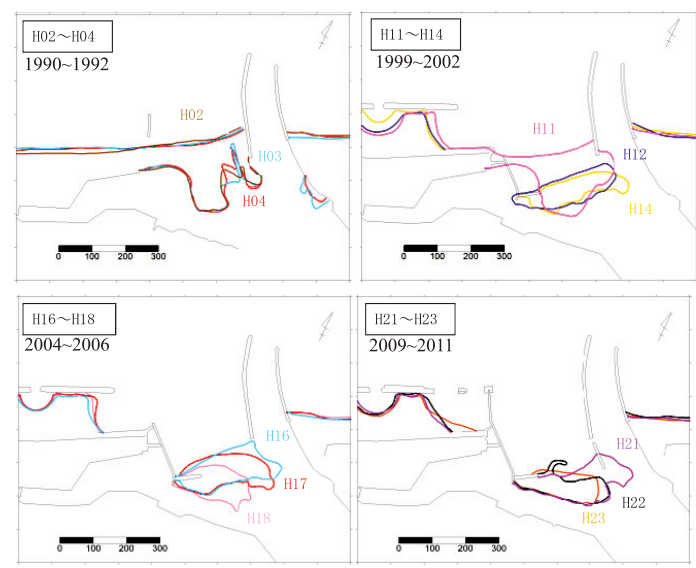

図-2 河口砂州形状の変遷

汀線形状（砂州形状）を読み取ったものである. 空中写 真は，毎年5月頃に撮影されている，図より，高津川河 口の砂州形状は, 1990年前半は西側の海岸から連続して おり，この頃は、洪水流下促進のための砂州開削が実施 


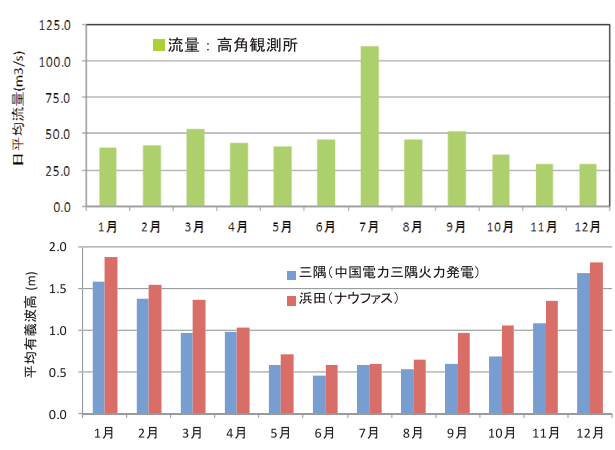

図-3 日平均流量（上）と有義波高（下）の月別平均値

されていた (宇多ら, 1997). その後, 1999年の出水で砂 州の左岸側が決壊して砂州が大きく上流側へ移動した。 2000 年に砂州の左岸側で防波堤が設置されて西側海岸と 分断された後は，徐々に上流側へ移動する傾向にある.

\section{（2）外力特性}

図-3は，高角観測所（河口より $2.4 \mathrm{~km}$ 上流）の 2000 年 〜 2011 年の日平均流量の月別平均值と浜田港 (NOWPHAS) 及び三隅の波浪観測データより月別平均 有義波高を整理したものである. 出水は夏季の7月に多 く, 波浪については, 夏季の平均有義波高は $0.5 \mathrm{~m}$ 程度で 静穏であり, 冬季は $1.8 \mathrm{~m}$ 程度であり, 来襲波浪の季節変 動が明瞭であった。 また，冬季（12月〜2月）の高波浪 の波向はNNW〜NNE方向で全体の $76 \%$ 占め, 波高 $2.5 \mathrm{~m}$ 以上の波は, $\mathrm{NNW}$ と $\mathrm{N}$ 方向からの来襲頻度が高い という特徴があった。 なお, 当海域の潮位差は $0.59 \mathrm{~m} て ゙$ ある。

\section{(3) 維持浚渫量}

図-4は, 高津川の日平均流量の月別最大值の経年変化 であり, 図-5は, 高津航路と大塚航路での維持浚渫土量 を示したものである. 高津航路と大塚航路では, 継続的 に維持浚渫が実施されており, その浚渫土砂は, 砂州及 び周辺海岸への養浜に活用されている. 維持浚渫量の実 績と流量の経年変化を比較すると, 夏季に大きな出水が あった翌年の維持浚渫土量が大きくなる傾向が認められ る. 出水の目安として, 日平均流量が $1000 \mathrm{~m}^{3} / \mathrm{s}$ 以上の大 出水がない年の浚渫量は平均 $10,000 \mathrm{~m}^{3}$, 大出水があった 年の浚渫量は平均 $25,000 \mathrm{~m}^{3}$ であり, このような出水は 2000 年以降の 11 年間で 3 回出現した.

\section{（4）底質特性}

砂州を構成する底質の特性は，2012年 5 月に現地踏査 を行い, 海岸線付近の表層底質を採取し, 粒度・比重 について調べた. その結果, 砂州の外周は, 中央粒径 $0.18 \sim 0.5 \mathrm{~mm}$ の細砂であった. 河口の左岸と右岸の底 質は, 中央粒径 $0.2 \sim 0.5 \mathrm{~mm}$ であり, 砂州を形成してい る砂とほぼ同じ粒径であった。また, 底質密度は, 全

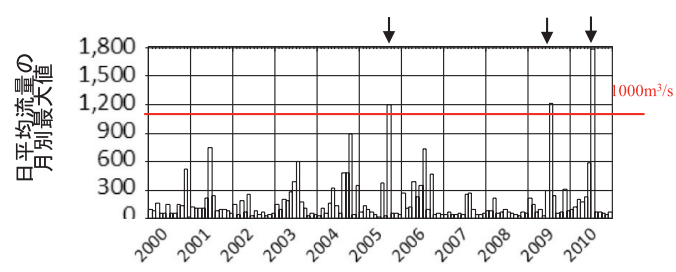

図-4 日平均流量の月別最大值

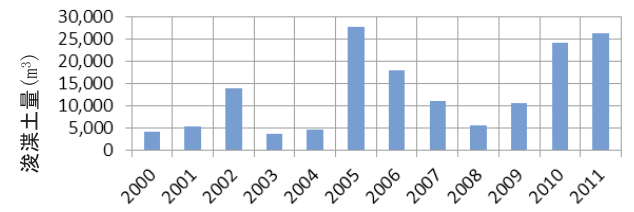

図-5 維持浚渫土量（高津航路＋大塚航路）の実積值

ての地点で $2650 \mathrm{~kg} / \mathrm{m}^{3}$ に近い值であり, 底質密度に違い はなかった。

\section{3. 航路埋塞メカニズムの検討}

上記の資料収集結果より，高津川河口では，出水や波 浪により河口砂州の変形が生じ, 砂州の背後に位置する 高津航路や大塚航路への砂の堆積が生じる. 特に, 夏季 の出水時の流量が大きい場合に, 航路の維持㴭渫量が大 きくなる傾向が認められた.

\section{（1）大出水による砂州地形変化}

高津川では, 2010 年 7 月に, 日平均流量が $1700 \mathrm{~m}^{3} / \mathrm{s}$ の 最近 10 年間で最大の出水が生じており, 図-6はその直後 の 2010 年 8 月に撮影された衛星写真である. 出水前の砂 州形状（図-1）と比較すると, 出水後の砂州形状は, 砂 州と中導流堤の基部の部分が開口し, 砂州が大きく決壊 した様子が確認される。また, 衛星写真の画像の色合い から, 図-6中に破線で示すように, 中導流堤と防波堤の 間で弓状に土砂の堆積域が形成された様子が確認された.

図-7は，2010年7月の出水時の高津川の流量の時間変

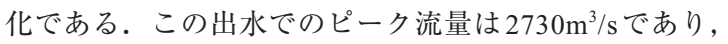

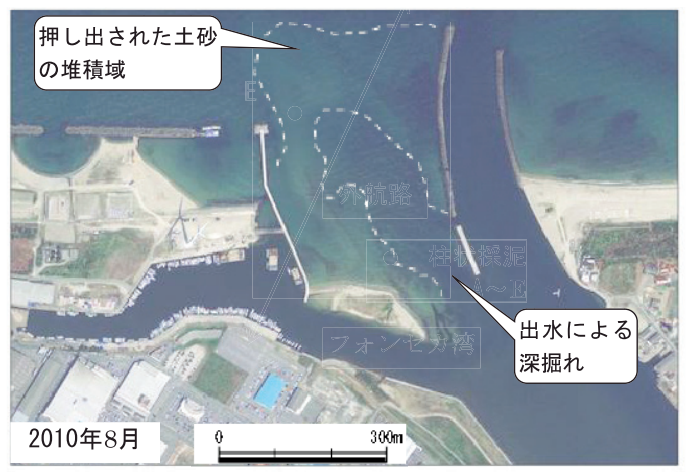

図-6 大出水 (2010年7月) 直後の砂州地形 


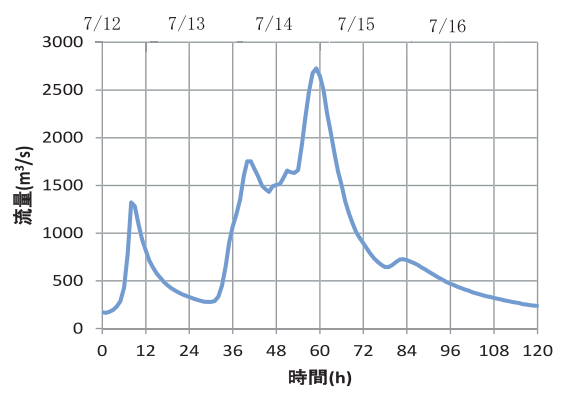

図-7 2010年7月の出水時の流量変化

高津川の計画流量 $\left(4900 \mathrm{~m}^{3} / \mathrm{s}\right)$ の約 $1 / 2$ の流量であった. また，最近 10 年間で日平均流量が $1000 \mathrm{~m}^{3} / \mathrm{s}$ を超える出水 は，2005年9月と 2009年7月に出現し，ピーク流量はそ

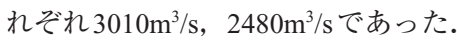

\section{（2）砂州の断面形状の変化}

2010 年 7 月の出水前後では, 深浅測量デー夕が取得さ れていないため，2005年9月の出水時を含む測量デー夕 より，砂州形状の変化を確認した．図-8は，河口部の岸 沖方向に設定された測線の内，砂州の中央部を通るL200 測線の岸沖断面の変化を示したものである. 断面変化は, 日平均流量が $1000 \mathrm{~m}^{3} / \mathrm{s}$ を超える大出水がなかった期間 （2004年 3 月～ 2005 年 4 月）と日平均流量 $1180 \mathrm{~m}^{3} / \mathrm{s}$ の大出 水（2005年9月 7 日）があった期間（2005 年 4 月〜 2006 年4月）の地形を比較したものである。また，測量は 3 月〜 4月であるため，地形変化には，大出水による変化 と冬季風浪による変化の両者の影響が含まれている.

出水なしの場合のL200測線の断面変化をみると，砂州 及びその背後の航路の水深に大きな変化はない。一方で, 砂州の沖側の断面変化は，沖側が侵食し岸側に堆積する 傾向を示している.

一方，出水があった場合の断面変化は，砂州の頂部付 近が大きく侵食して砂州高が低下し，高津航路側に堆積 が生じていることが特徴である．出水時には，図-6の写 真に見られるように，砂州を形成していた土砂が沖側に 大きく流出することから，出水によって流出した土砂が その後の冬季風浪によって岸側に運ばれ，一部は砂州の 再形成に，一部は更に押し込まれて砂州背後に位置する 航路へ落ち込んたもものと考えられる。また，水深- $2 \mathrm{~m}$ よ り深い部分の形状はほとんど変化がないことから，砂州 の沖側の地形は出水の影響で変形が生じたとしても，冬 季風浪の作用を受けた後の砂州の沖側地形は元の地形に 近い形状に復元したものと考えられる.

以上のことから，高津川の河口砂州は，大出水により 砂州が決壊し，その後の冬季風浪によって決壊部分から 波浪が侵入することによって，土砂が航路内に移動・埋 没するという経過をたどっているものと推定される.
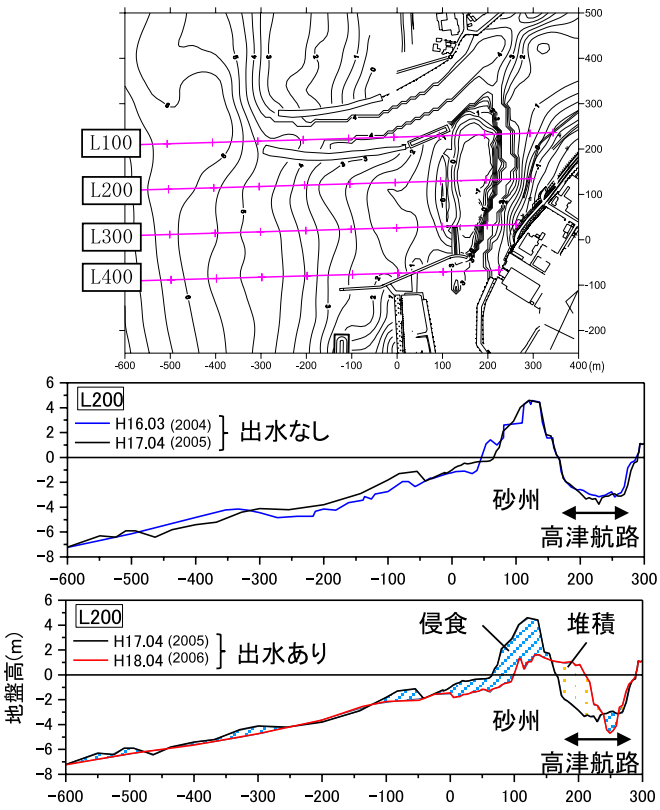

図-8 出水の有無による砂州周辺地形の変化

\section{4. 地形変化の数値シミュレーション}

高津川河口域の河口砂州の変形に伴う航路埋塞につい て，(1)大出水による砂州の決壊と(2)波浪による土砂の押 し込みまでの一連の現象について，地形変化シミュレー ションを行った。

\section{（1）計算モデルの概要}

計算モデルは，水深積分型の連続式と運動方程式を基 礎式とする平面2次元流動モデルと, van Rijn（1984）の 巻き上げ量算定式に基づく浮遊砂の移流拡散モデルによ り水深変化を計算するものである.

計算地形として，海岸域，河口域の測量デー夕を基に， 高津川河口海域（東西 $2650 \mathrm{~m} \times$ 南北 $2950 \mathrm{~m}$ ）を $10 \mathrm{~m}$ メッ シュで近似した地形データを用いた。構造物の条件とし ては，防波堤にのみ反射率 0.9 (直立壁) を与え，他の構 造物（導流堤及び護岸）については不透過の非計算格子 に設定した。また，底質条件は砂州を形成する砂の平均 粒径である $0.2 \mathrm{~mm}$ の細砂とした。

\section{(2) 出水時の地形変化計算}

出水時の計算は，海側境界では潮位一定（M.S.L.）と し，河川流入境界に打いて，図-7に示す流量変化を入力 条件として計算を抢こなった。

図-9は，流量ピーク時における流速ベクトルの分布図 であり，図-10は，砂州の決壊箇所（Pt.A）の流速及び水 深の時間変化と, 益田港内 (Pt.B) の水位の時間変化及 び流量ピーク時の益田港内の状況写真である. 図より, 流量の変化に応じて港内の水位が変動することや，流量 


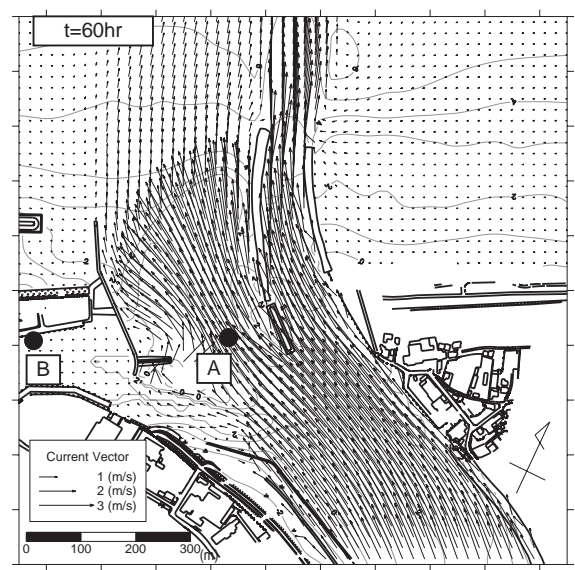

図-9 出水の有無による砂州周辺地形の変化
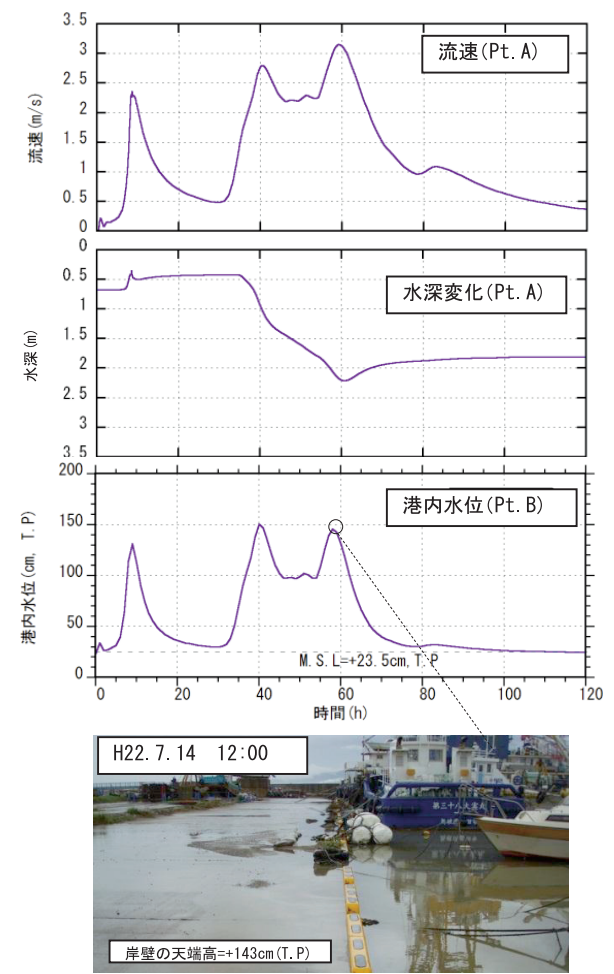

図-10 出水時の砂州上の流速、水深と港内水位の変化

ピーク時には益田港内の写真より，岸壁（物揚場）の高 さ $(=+1.43 \mathrm{~m})$ まで水位が上昇し, 計算結果のピーク時 水位とよく整合していることが確認された。また，開口 部の水深変化は，35時間後から流量が最大となる 60 時間 後までの間で急激に侵食が生じる結果であった。

図-11に, 出水による地形変化の侵食堆積量の分布図 を示す. 出水による地形変化は, 強い流れにより土砂が 沖側へ流出し, 導流堤基部付近で深掘れし, 導流堤の沖 側端付近まで弓状の堆積域が形成される状況など，図-6

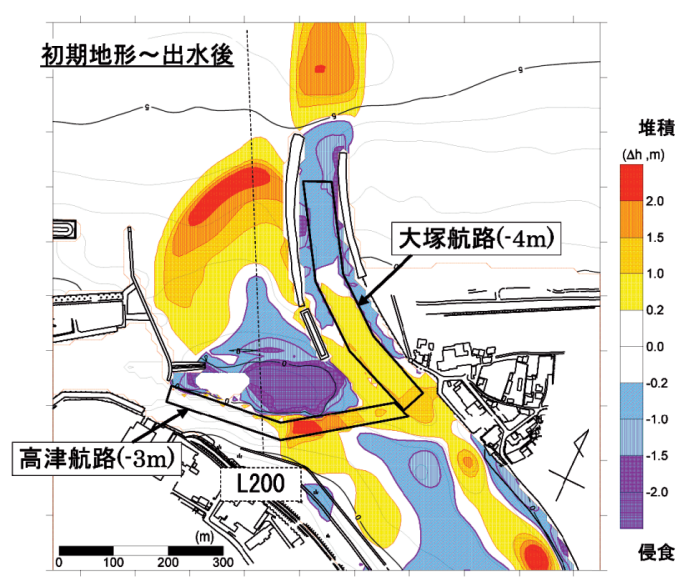

図-11出水による砂州地形変化の計算結果

の写真に見られる状況がよく再現されている，また，砂 州決壊に伴って強い流れが発生する高津航路の東側半分 の範囲では, 航路への土砂堆積が生じている。

\section{（3）波浪による地形変化計算}

波浪による地形変化は, 出水により砂州が決壊した後 の地形を初期地形とし, 波浪一海浜流一地形変化の繰り 返し計算を行った。夏季の出水後（7月）～冬季風浪後 (2月)までの期間を対象とし, 河川流は平水流量 $\left(50 \mathrm{~m}^{3} / \mathrm{s}\right)$, 波浪条件は夏季（波高 $=1.1 \mathrm{~m}$, 周期 $\left.=6.3 \mathrm{~s}\right)$, 秋 季（波高 $=2.3 \mathrm{~m}$, 周期 $=7.7 \mathrm{~s}$ ， 冬季（波高 $=3.1 \mathrm{~m}$, 周期 8.3s）の3段階の代表波浪を用いて計算した. 代表波浪は, 季節別の波浪の出現頻度を整理して, 各期間の超過確率 $10 \%$ の波浪条件を抽出し, 各期間の全波作用エネルギー フラックスと等価となるよう作用時間を設定した。また， 波向は全てNNWとした.

図-12 は, 地形変化の計算過程での冬季波浪作用時の 海浜流の分布を示したものである. 砂州と導流堤間が開 口した地形に波浪が作用するため，上流側に開口部へ向 かう海浜流が形成されている.

図-13 は, 出水後から冬季波浪作用後の地形変化の計 算結果（侵食堆積量の分布）を示したものである。波浪 による地形変化の計算では, 出水により沖に張り出した 砂州地形が, 波の作用によって形が崩れ, 図-12に示す ような海浜流によって岸向き土砂移動が生じ, 出水で沖 側に堆積した土砂が岸側に輸送され, 深掘れした部分が 埋め戻されるとともに高津航路への堆積が生じている.

図-14 は，図-11 及び図-13 中に示すL200 測線の断面変 化をプロットしたものである. 水面より上部への砂州の 再形成は再現されていないものの, 図-8に示した測量結 果と同様に, 出水で沖側に流出した地形が元の海浜断面 形状に近づく様子や波浪の押し込みによる高津航路への 土砂堆積が再現されている. 


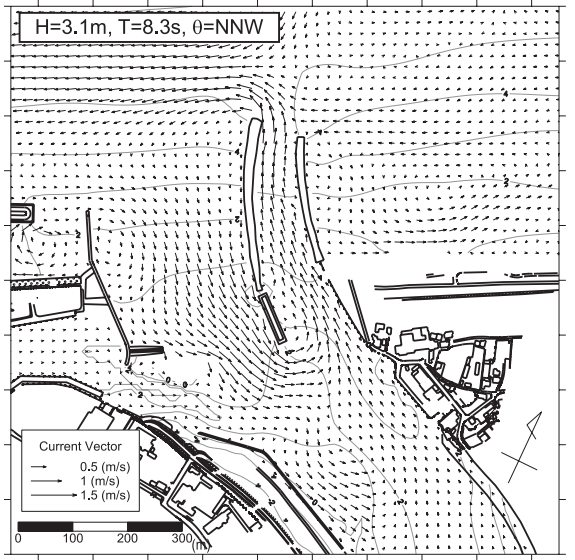

図-12 高波浪（冬季）作用時の海浜流分布

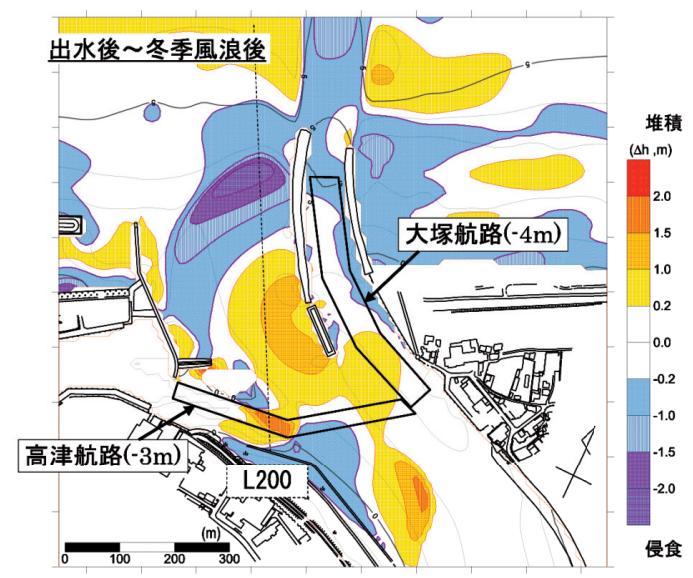

図-13 波浪による砂州地形変化の計算結果

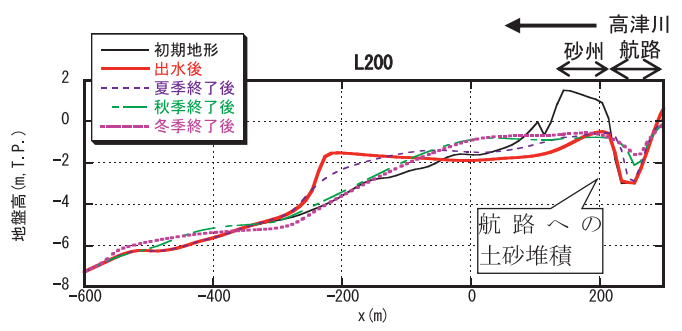

図-14 砂州の決壊とその後の波浪による断面地形変化

\section{（4）航路堆積量の評価}

地形変化の計算結果より, 高津航路と大塚航路への堆 積土量を算定した。堆積土量は, 侵食・堆積量の計算結 果より, 図中に示す高津航路と大塚航路の範囲内の堆積

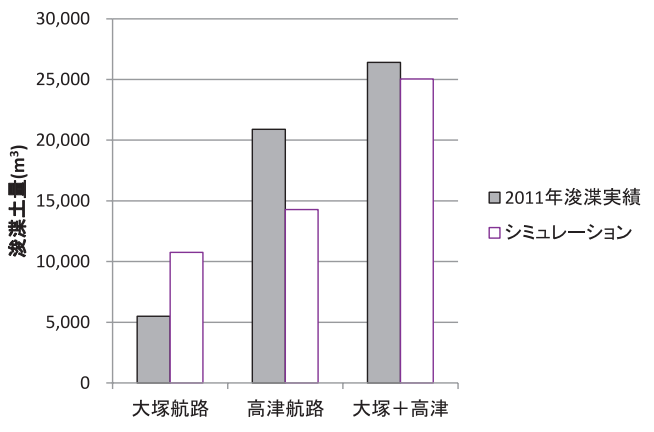

図-15 航路埋塞土量の比較

量のみを集計した。計算結果と浚渫土量の実積值を比較 した結果を図-15に示す。浚渫量の実積值は，高津航路 の浚渫量が大塚航路より大きく，両者を合わせると約 $25,000 \mathrm{~m}^{3}$ であった。計算結果と比較すると, 航路別の堆 積量は浚渫実積量と異なるけれども, 両航路の総堆積土 量は浚渫実積量と概ね一致した。

\section{5. まとめ}

高津川河口を対象に，砂州の変形と対応した航路埋塞 過程について, 収集可能なデータより分析し, 地形変化 シミュレーションにより再現した。

高津川の河口航路では, 大出水時の砂州の決壊に伴う 航路への堆積と, 冬季風浪で決壊部分から波浪が侵入す ることに伴う航路への堆積が生じる.

出水時の地形変化シミュレーションょり, 砂州決壊 時の地形変化の特徵や, 港内水位の上昇を良好に再現 した.

波浪による砂州の回復過程について, 波浪特性の季節 変化を考慮した地形変化計算をおこない, 出水時に流出 した土砂が岸側に移動し，砂州背後の航路埋塞を引き起 こす状況を再現した.

謝辞：本研究は，「益田港航路埋塞対策検討委員会」に おいて，委員各位と関係者より貴重なご意見を頂いた。 また，島根県益田県土整備事務所よりデー夕提供をご協 力頂いた.ここに記して，謝意を表します.

\section{参 考 文 献}

宇多高明 - 福田清隆 ·上田源一 - 木原 均 - 戸川光司 （1997）：高津川河口部における河口処理と海岸侵食につ いて, 海岸工学論文集、第44巻, pp.566-570.

Van Rijn, L. C. (1984): Sediment transport: Part II, Suspended load transport, J. Hydraulic Eng., Vol. 11, pp. 1613-1641. 